\title{
Some Properties of Three Related Viruses: Andean Potato Latent, Dulcamara Mottle, and Ononis Yellow Mosaic
}

\author{
By A. J. GIBBS, EVA HECHT-POINAR AND R. D. WOODS \\ Rothamsted Experimental Station, Harpenden, Hertfordshire \\ AND R. K. MCKEE \\ John Innes Institute, Bayfordbury, Hertford, Hertfordshire
}

(Received 30 November 1965)

\begin{abstract}
SUMMARY
Three similar and apparently previously unrecorded viruses were studied and found to be most like viruses of the turnip yellow mosaic group. Andean potato latent virus (APLV) was obtained from primitive cultivated potatoes collected in the high tropical Andes, dulcamara mottle virus (DMV) from Solanum dulcamara L. growing near Rothamsted, and Ononis yellow mosaic virus from Ononis repens L. growing in many parts of England. All three viruses are readily transmitted by sap inoculation; APLV and DMV are transmitted through the seed of infected plants; DMV is transmitted by the flea beetle Psylloides affinis Paykull. Plants infected by one of the viruses are not protected against infection by the others.

Purified preparations of these viruses have many common properties. Each virus has isometric particles $25-30 \mathrm{~m} \mu$ in diameter, indistinguishable in appearance from one another and from the particles of turnip yellow mosaic virus. Preparations of each contain mainly two types of particles with sedimentation coefficients of about $115 \mathrm{~S}$ and $55 \mathrm{~S}$, corresponding to infective nucleoprotein particles and non-infective 'empty' particles respectively. Each contains nucleic acid with a molar base composition of about $\mathrm{G} 16 \% \mathrm{~A} 22 \% \mathrm{C} 33 \% \mathrm{U} 29 \%$. The three viruses are serologically related; antisera titres are 8-128 times greater with homologous than with the heterologous viruses. No serological relationship was found between these viruses and turnip yellow mosaic, wild cucumber mosaic, cocoa yellow mosaic, squash mosaic and red clover mottle viruses.

Plants infected with APLV or DMV when sprayed with solutions of 2-thiouracil or 6-azauracil produced fewer nucleoprotein particles and more 'empty' protein particles, than plants sprayed with water.
\end{abstract}

\section{INTRODUC'TION}

In 1962 plants of Restharrow (Ononis repens L: Papilionaceae) showing a bright yellow mosaic were found growing on the cliffs near Tintagel in Cornwall, England. A virus was obtained from these plants by inoculating their sap to plants of several other herbaceous species; from these plants the virus was transmitted by sap to healthy $O$. repens plants, which then developed the bright yellow mosaic. This virus, which we called Ononis yellow mosaic virus (OYMV), aroused interest because its particles closely resemble those of turnip yellow mosaic virus (TYMV). A second virus, whose particles also resemble those of TYMV, and which is 
serologically related to OYMV, was obtained from several clones of potatoes in the Commonwealth Potato Collection at the John Innes Institute, Hertford, England. These clones had been collected from the tropical Andes and had been tested for all the common potato viruses (McKee, 1964). In further tests, seedlings of a line of Solanum stoloniferum Schlechdt. et Bché, which is immune to potato virus Y (PVY), were inoculated with sap from 80 clones of Andean potatoes infected with PVY, to see whether any of the Andean isolates of PVY overcame this resistance. None of the inoculated plants became infected with PVY but some developed a mild mosaic, and were found to contain a virus, apparently unlike any of the many viruses previously found in potato, which we propose to call Andean potato latent virus (APLV). Attempts to transmit APLV from infected to healthy $S$. stoloniferum plants using the potato flea beetle Psylloides affinis Paykull failed, but a third virus, which was related to OYMV and APLV, was isolated from the Solanum dulcamara L. plants from which the potato flea beetles had been collected. This virus, which we called dulcamara mottle virus (DMV), was transmitted by the flea beetles.

In this paper we describe the occurrence and distribution of these three viruses, together with some of their properties, particularly those which seem useful for comparing them with other known viruses.

\section{METHODS}

The isolate of APLV, which we used for all our tests, was obtained from a clone of diploid potatoes (group Phureja) originally from Sogamoso, Colombia (Commonwealth Potato Collection No. 2853). It was maintained in Nicotiana glutinosa L. and Solanum stoloniferum. The stock isolate of DMV was obtained from naturally infected Solanum dulcamara and was kept in plants of $N$. glutinosa. The stock isolate of OYMV used came from an Ononis repens plant collected at Tintagel, Cornwall. These stock cultures and all test plants were kept in insect-free glasshouses at $16-24{ }^{\circ}$.

The stability of the viruses in untreated sap from diseased plants was estimated as suggested by Bos, Hagedorn \& Quantz (1960). They all proved stable and could be purified by several methods, but the following one was mostly used. Infected leaves were triturated mechanically in half their weight of $\mathrm{pH} \mathbf{7 \cdot 0}$ buffer containing $\mathbf{0 . 0 5} \mathrm{M}$-ascorbic acid and $\mathbf{0 \cdot 1} \mathrm{M}$-disodium hydrogen phosphate. Chloroform and $n$-butanol, each one-quarter the volume of the buffer, were added and the mixture triturated further to form an emulsion which was centrifuged for $8 \times 10^{4} \mathrm{~g} \mathrm{~min}$. $(8000 \mathrm{~g}$ for $10 \mathrm{~min}$.), and the aqueous phase collected. The virus in this aqueous extract was further purified and concentrated by two or more cycles of differential centrifugation; $11 \times 10^{6} \mathrm{~g}$ min. and $8 \times 10^{4} \mathrm{~g}$ min. using $0.03 \mathrm{M}$-phosphate buffer $\mathrm{pH} 7 \cdot 0$ as the suspending fluid. All three viruses could be purified in other ways, for example, APLV was fully and reversibly precipitated in half-saturated ammonium sulphate solution or in $20 \%$ ethanol solution.

Purified preparations of the viruses were examined in a Siemens Elmiskop I electron microscope using the methods described by Nixon \& Harrison (1959).

Preparations, suspended in $\mathbf{0} \cdot \mathbf{1} \mathrm{m}$-potassium chloride solution $\mathrm{pH} \mathbf{7 \cdot 0}$, were examined in a Spinco Model $\mathrm{E}$ analytical centrifuge using the schlieren optical system, and the sedimentation rates of the different components of the preparations 
estimated by a graphical method (Markham, 1960). Each virus preparation was examined at 3-6 different concentrations (from about 0.1 to $5.0 \mathrm{mg} . / \mathrm{ml}$.), and the results obtained extrapolated to infinite dilution by calculating a regression line by the least squares method.

Nucleic acid was extracted from the viruses by incubating them at $18^{\circ}$ in $\mathrm{N}-\mathrm{HCl}$ for $12 \mathrm{hr}$. The base composition of the nucleic acids was estimated by a chromatographic method similar to that described by Markham (1955), using a tertiary butanol $+\mathrm{HCl}$ solvent, and the fluorescent screen described by Katz (1962) to detect the spots. Two or three estimates of the base composition were made on each of three or four separate preparations of each virus; the result given for each virus is the average of seven to eleven determinations. To check our application of the method we also estimated the base composition of tobacco mosaic and turnip yellow mosaic viruses, and obtained results within $5 \%$ of those quoted by Markham (1959).

Antisera were prepared by injecting rabbits intravenously at weekly intervals with purified virus preparations (about $1 \mathrm{mg}$. virus/injection). Each rabbit was injected four times and was bled 10 days after the last injection. Quantitative tests for assessing the serological relationships between viruses were done by the tube precipitation method (Bawden, 1950). A micro gel diffusion method (Mansi, 1958) was used as a qualitative test for virus in plant saps. The serological relationships between the viruses were estimated by (1) determining the precipitation end-points of the antisera when titrated against purified preparations of the three viruses, and (2) the precipitation end-points of each serum after it had been absorbed with an excess of each of the viruses. First, the concentration of virus in each preparation was found by titrating it against its homologous antiserum, the preparation was then used at a constant concentration (approximately four times that of the precipitation end-point; about $20 \mathrm{mg}$. $/ \mathrm{l}$.) to find the titres of the various antisera.

The viruses and antisera used in the serological and other tests were from various sources. The Virus Research Unit, Cambridge, kindly supplied the Cambridge strain of turnip yellow mosaic virus; also wild cucumber mosaic virus and its antiserum. The strain of cocoa yellow mosaic virus and its antiserum were those used by Brunt, Kenten, Gibbs \& Nixon (1965). D. G. Robertson, Moor Plantation, Ibadan, Nigeria, kindly supplied the cowpea mosaic virus, and R. J. Shepherd, then at the Department of Plant Pathology, University of Wisconsin, U.S.A., the squash mosaic virus. The red clover mottle virus isolate was that described by Sinha (1960), and the antisera against turnip yellow mosaic, cowpea mosaic, red clover mottle, and squash mosaic viruses were all prepared at Rothamsted.

\section{RESULTS}

Biological behaviour

\section{Symptoms shown by naturally-infected plants}

Several of the primitive cultivated potatoes from which Andean potato latent virus (APLV) was isolated showed mosaic symptoms and leaf distortion, but these symptoms were apparently caused by other viruses (Table 1) for there were no symptoms common to all APLV-infected clones.

Solanum dulcamara plants infected with dulcamara mottle virus (DMV) showed 
a very mild mottling and slight puckering of the leaves, especially those produced during cool weather (Pl. 1, fig. 1). Older leaves senesced prematurely.

Plants of Ononis repens infected with Ononis yellow mosaic virus (OYMV) showed a chlorotic mosaic (Pl. 1, fig. 2), brightest during the spring, but still evident even in the hottest weather. Infected plants were not noticeably stunted, their growth form was normal, they produced normal flowers without a colour break, and set viable seed.

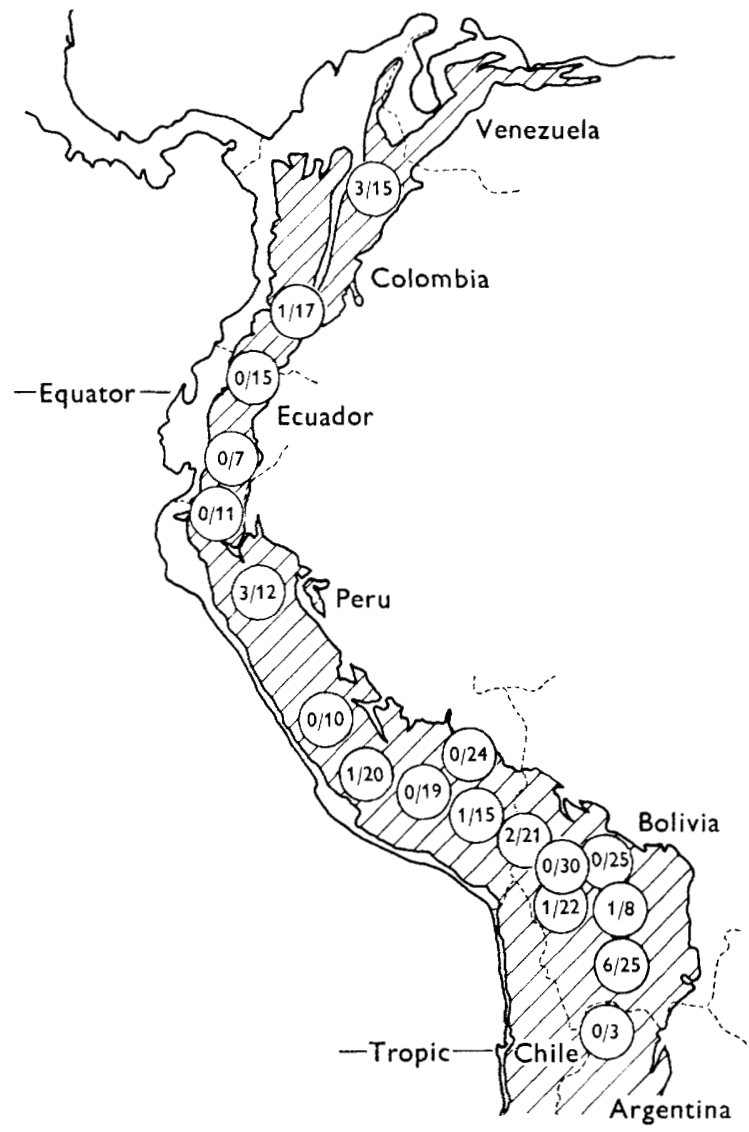

Fig. 1. Sites in tropical Andes from which potatoes infected with APLV were collected; at each site the numerator is the number of potatoes from that site found to be infected, denominator the total number of potatoes collected at that site.

\section{Geographical distribution}

In 1964 all the potato clones in the Commonwealth Potato Collection were tested serologically for APLV. Nineteen clones were found to be infected; all these came from a wide range of localities (Fig. 1 and Table 1) in the tropical Andes (John Innes Institute Report, 1960, 1963) where potatoes grow only at high altitudes. APLV was not found in any of the other potatoes in the Collection, which consisted of a further $\mathbf{2 8 0}$ clones from the tropical Andes, $\mathbf{1 3 2}$ clones from temperate Chile, and 131 stocks of cultivars from various sources including Great Britain, The Netherlands, and the U.S.A. 
DMV was isolated from Solanum dulcamara plants from Streatley, Bedfordshire in 1964. The plants were growing in scrub-land on the slope of a chalk escarpment, and in hedgerows nearby. Sap from these plants was inoculated to Nicotiana glutinosa plants, which developed symptoms a week later. Sap from infected $N$. glutinosa and $S$. dulcamara reacted strongly in gel diffusion serological tests with DMV antiserum. About one-quarter of the $S$. dulcamara plants at Streatley were infected with DMV, but the virus was not isolated from a further $230 \mathrm{~S}$. dulcamara plants collected from 31 sites in central and southern England (Fig. 2); some of the plants from three of the sites were infected with cucumber mosaic virus.

Table 1. APLV-infected primitive potato clones; type, source, other viruses

\begin{tabular}{|c|c|c|}
\hline Type of potato* & $\begin{array}{l}\text { Other } \\
\text { virusest } \\
\text { isolated } \\
\text { from the } \\
\text { clone }\end{array}$ & Provenance \\
\hline
\end{tabular}

Solanum tuberosum L. group Phureja (diploid)

S. tuberosum L. group Chaucha (triploid)

S. tuberosum L. group Andigena (tetraploid)

\begin{tabular}{|c|c|c|}
\hline X, L.R. & Nr. Pamplona, Colombia & 2848 \\
\hline $\mathbf{X}, \mathbf{Y}$ & Sogamoso, Colombia & 2853 \\
\hline $\mathbf{S}$ & Nr. Firavitoba Colombia, & 2865 \\
\hline $\mathbf{S}, \mathbf{Y}$ & Nr. Ipiales, Colombia & 2942 \\
\hline $\mathbf{X}$ & Huanucu, Peru & 1777 \\
\hline $\mathbf{x}$ & & 2771 \\
\hline $\mathbf{x}$ & Potosi, Bolivia & 2775 \\
\hline $\mathbf{Y})$ & & 2781 \\
\hline - & Huancabamba, Peru & 3019 \\
\hline $\mathbf{X}, \mathbf{S}$ & Huaraz, Peru & 3043 \\
\hline $\mathbf{S}$ & Ayacucho, Peru & 3054 \\
\hline - & Nr. Acora, Peru & 3125 \\
\hline $\mathbf{x}$ & La Paz, Bolivia & $3166 B$ \\
\hline - & Oruro, Bolivia & $3177 \mathrm{~A}$ \\
\hline - & Sucre, Bolivia & 3188 \\
\hline L.R. $\}$ & Nr. Potosi, Bolivia & $\{3190$ \\
\hline $\mathbf{S}\}$ & Nr. Folusi, Duilvia & $\{3191$ \\
\hline $\mathbf{X}$ & Potosi, Bolivia & 3195 \\
\hline - & Batallas, Bolivia & 3655 \\
\hline
\end{tabular}

S. tuberosum L. (group undetermined)

* Nomenclature that of Dodds (1962).

$\dagger \mathbf{X}$, potato virus $\mathbf{X} ; \mathbf{Y}$, potato virus $\mathbf{Y} ; \mathbf{S}$, potato virus $\mathbf{S}$; L.R., potato leaf roll virus.

$\ddagger$ Commonwealth Potato Collection number.

In 1963 and 1964 restharrow growing in many parts of England and Wales was inspected and tested for OYMV. Although restharrow has been recorded in all lowland areas of Britain (Perring \& Walters, 1962) it is uncommon and difficult to find except on recently-stabilized sand dunes. We mostly inspected restharrow on coastal sand dunes therefore, and may have obtained an unrepresentative sample of the total restharrow population. Restharrow was sampled at 24 sites (Fig. 3), at each site 20-80 (average 32) shoots were collected at random. The shoots were inspected for symptoms, and sap from them inoculated to pea plants, all of which were later tested serologically for OYMV. OYMV was found in all parts of southern Britain, though perhaps it is more common in the south-west (Fig. 3). Ononis spinosa L., the only other common restharrow in Britain, mainly occurs in central, eastern, and southern England. Many plants of $O$. spinosa from six sites, some near infected Ononis repens, were tested for OYMV, but apparently none were infected, 
though in glasshouse tests $O$. spinosa plants were readily infected when rubbed with sap containing OYMV.

\section{Natural transmission}

(a) Seed. In limited tests APLV and DMV, but not OYMV, were transmitted through the seed of infected plants. Seed from APLV-infected Nicotiana clevelandii Gray and Petunia hybrida Villm produced seedlings that looked healthy, but sap inoculation tests showed that the $N$. clevelandii seedlings were infected.

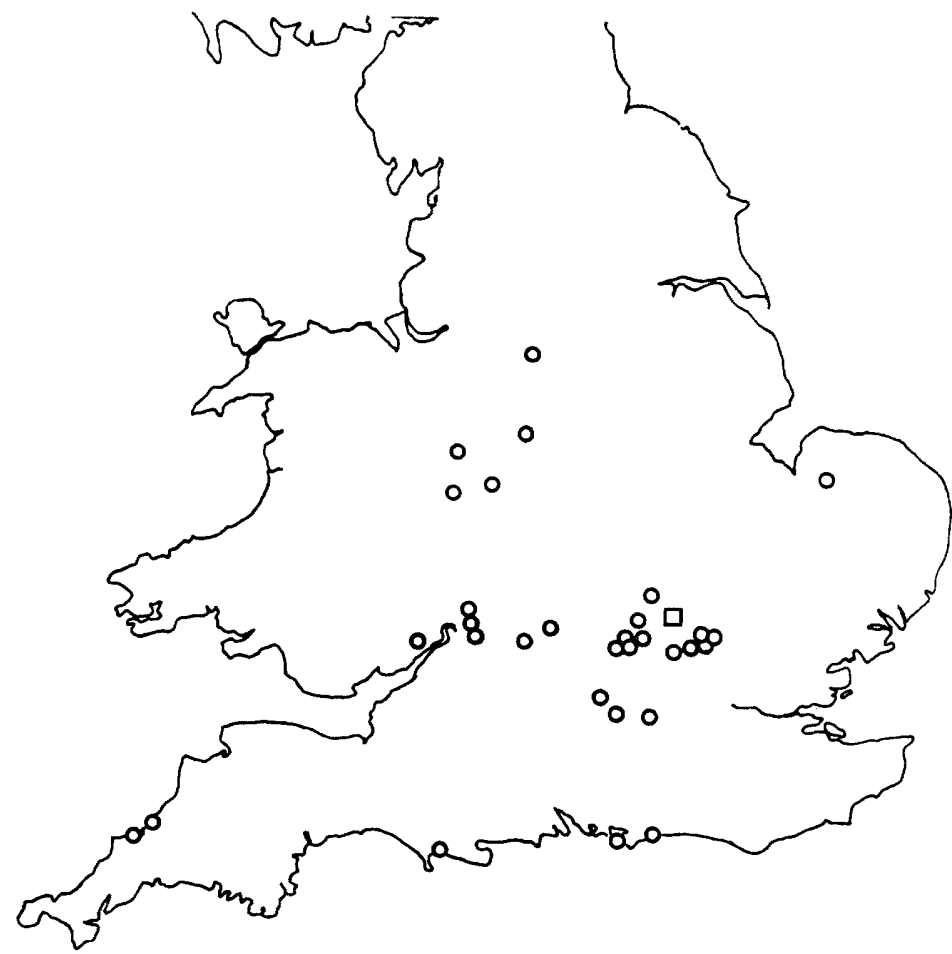

Fig. 2. Sites in England from which $S$. dulcamara shoots were collected; circles at sites from which no DMV was isolated, square at the site where DMV was found.

Seeds collected from infected Solanum dulcamara plants growing wild were germinated in the glasshouse, and the seedlings tested, either singly or in groups of two, four or eight by inoculating their sap to Nicotiana glutinosa. One infected seedling was found in the 441 seedlings tested, and it showed clear symptoms. Fifty seedlings grown from seeds collected from naturally-infected restharrow plants at Tintagel were tested by inoculating their sap to pea plants, but none was virus infected.

(b) Insects. The two related viruses turnip yellow mosaic and wild cucumber mosaic are transmitted by Halticid and Galerucid flea beetles (Markham \& Smith, 1949; Freitag, 1952). APLV, DMV and OYMV in many ways resemble these viruses; experiments were therefore done to see whether they have similar vectors. During 1963 and 1964 insects were collected by sweeping and beating from restharrow plants at many sites. At most of the sites the pea aphid Acyrthosiphon pisum Harris and the Mirid bug Macrotylus paykulli Fall. were common, at a few sites the 
Collembolan Sminthurus viridis L. was common, and the weevil Apion ononis Kirby was found at three-quarters of the sites where OYMV was found. The bug, the collembolan, and the weevil failed to transmit OYMV to healthy restharrow plants, though all fed on the restharrow test plants. A total of 100-200 individuals of each insect were used, either collected from diseased plants in the field and caged immediately on healthy test plants, or fed for various periods on diseased plants in

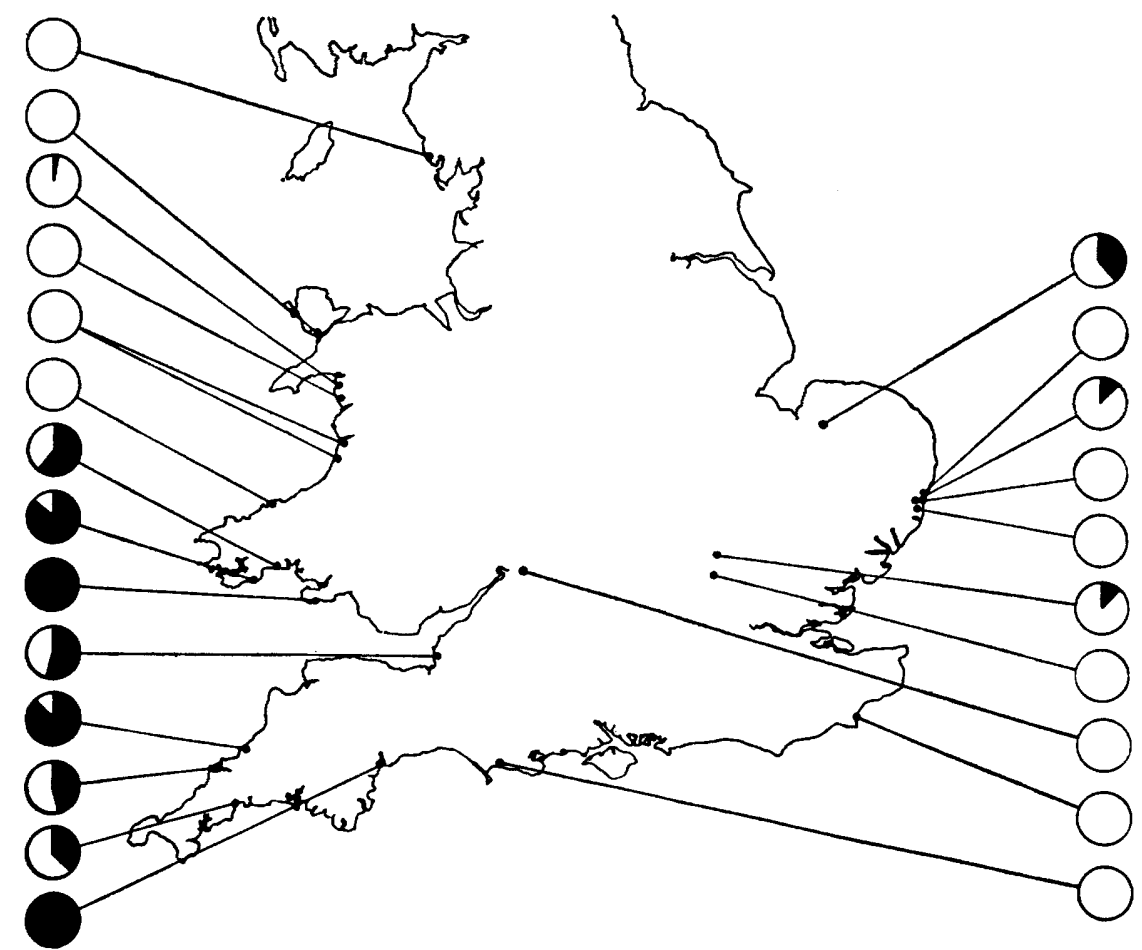

Fig. 3. Sites in England and Wales from which 0 . repens shoots were collected; black sector shows the proportion of shoots from each site infected with OYMV.

cages before being put on healthy plants. Several unidentified species of grasshopper were also found on the restharrow at most sites, and a single flea beetle Crepidodera ferruginea Scop. at one site; neither the flea beetle nor the grasshoppers fed on restharrow plants on which they were caged, and none of the plants became infected.

The potato flea beetle Psylloides affinis Paykull. also failed to transmit APLV from diseased to healthy Solanum stoloniferum plants, for the beetles, collected from wild Solanum dulcamara plants, would not feed on the $S$. stoloniferum plants. Several attempts were made to transmit DMV from diseased to healthy $S$. dulcamara plants by potato flea beetles collected from wild $S$. dulcamara plants. During the summer of 1964 about 150 first generation beetles were fed on an infected plant for one day and then caged on healthy plants, none of which became infected. In the autumn second generation beetles were collected, fed on an infected plant, and 48 of them caged in pairs on healthy seedlings, four of which became infected. In a third experiment, done later in the autumn when most wild $S$. dulcamara plants were almost 
leafless, none of forty moribund beetles transmitted the virus. On each occasion at least one quarter of the beetles collected were caged on healthy test plants, but none of these became infected. In the spring of 1965 more beetles were collected from naturally-infected $S$. dulcamara showing symptoms. Four groups of twenty beetles were each caged on twenty $\boldsymbol{S}$. dulcamara seedlings growing in a box. Two seedlings in one box and one in another became infected. When the experiment was repeated one month later, in hotter weather, none of the test plants became infected.

\section{Experimentally-infected plants}

Several different species of plants were inoculated with the three viruses. Most were inoculated by dusting their leaves with carborundum and then rubbing them with sap from either infected restharrow or pea (OYMV) or infected Nicotiana glutinosa (APLV or DMV). Some cultivated potato varieties were also grafted with scions of primitive potato or $N$. glutinosa infected with APLV or DMV respectively. All inoculated plants were tested 3-6 weeks later for infection by inoculating their sap to appropriate test plants; the presence of virus in plants showing symptoms was also checked serologically. Plants were most readily infected during cool weather and few became infected during hot summer weather; though APLV was transmitted by grafting at all times.

APLV infected more of the species inoculated than did OYMV or DMV (Table 2), though OYMV but not APLV or DMV infected several leguminous species. Only three species, all Solanaceae, were infected by all three viruses. None of the viruses infected Brassica chinensis L. or Cucurbita pepo L., which are susceptible to turnip yellow mosaic and wild cucumber mosaic viruses respectively, and only APLV infected Chenopodium amaranticolor Coste \& Reyn, which is susceptible to cocoa yellow mosaic virus. It is interesting that APLV infected Chenopodium quinoa Willd., which is grown as a grain crop in the region of the Andes where the APLV-infected potatoes were collected.

The symptoms caused in the plants we found most useful or in other ways noteworthy are described below.

Andean potato latent virus. During hot weather infected Nicotiana glutinosa showed slight or no symptoms. In cool weather inoculated leaves showed indistinct chlorotic and necrotic local lesions. Systemically infected young leaves showed vein clearing (Pl. 1, fig. 3), those produced later were distorted and showed a chlorotic mosaic with necrotic flecking. APLV was transmitted by sap inoculation or grafting to many species of the Solanaceae, and infected all systemically, except Solanum dulcamara. In most, including the cultivated potato varieties, it caused slight or no symptoms. APLV infected two Chenopodium species causing indistinct necrotic and chlorotic flecking of the inoculated leaves and, occasionally, the tip leaves.

Dulcamara mottle virus. The symptoms in Nicotiana glutinosa during hot weather resembled those caused by APLV during cool weather, and in cool weather were much more severe; the tip leaves became distorted and crinkled because of necrosis of the leaf veins (Pl. 1, fig. 4). DMV caused more noticeable symptoms than APLV in most of the plants it infected, especially in N. glutinosa and Nicotiana clevelandii but, even when grafted with infected $N$. glutinosa, potatoes did not become infected. There was great seasonal variation in the susceptibility of Solanum dulcamara to sap 
Table 2. Hosts of APLV, DMV and OYMV

\begin{tabular}{|c|c|c|c|c|}
\hline Amaranthaceae & Gomphrena globosa L. & + & - & - \\
\hline Apocynaceae & Vinca rosea $\mathrm{L}$. & . & - & - \\
\hline Chenopodiaceae & $\begin{array}{l}\text { Chenopodium amaranticolor Coste \& Reyn } \\
\text { C. foetidum Schrad. } \\
\text { C. quinoa Willd. }\end{array}$ & $\begin{array}{l}+ \\
\dot{+}\end{array}$ & $\begin{array}{l}- \\
-\end{array}$ & $\begin{array}{l}- \\
-\end{array}$ \\
\hline Cruciferae & Brassica chinensis L. 'Pe. tsai' & - & - & - \\
\hline Cucurbitaceae & $\begin{array}{l}\text { Cucumis sativus L. 'Everyday' } \\
\text { Cucurbita pepo L. }\end{array}$ & - & - & - \\
\hline Gramineae & $\begin{array}{l}\text { Hordeum vulgare } \mathbf{L} \text {. 'Proctor' } \\
\text { Triticum aestivum L. 'Cappelle' }\end{array}$ & - & $\dot{.}$ & - \\
\hline Papilionaceae & $\begin{array}{l}\text { Glycine soja (L.) Sieb. et Zuec. 'Lincoln' } \\
\text { Medicago sativa L. 'Du Puits' } \\
\text { Ononis repens L. } \\
\text { O. spinosa L. } \\
\text { Phaseolus vulgaris L. 'Prince' } \\
\text { Pisum sativum L. 'Onward' } \\
\text { Trifolium incarnatum L. } \\
\text { T. repens L. 'S. 100' } \\
\text { Vicia faba } \text { L. 'The Sutton' } \\
\text { Vigna sinensis (L.) Endl. 'Paraguay } 6 \text { ' }\end{array}$ & $\begin{array}{l}\dot{\cdot} \\
\dot{.} \\
\dot{-} \\
- \\
- \\
- \\
-\end{array}$ & $\begin{array}{l}\dot{.} \\
- \\
\dot{-} \\
- \\
- \\
- \\
.\end{array}$ & $\begin{array}{l}+ \\
+ \\
+\mathbf{N} \\
+ \\
- \\
+ \\
+ \\
+ \\
-\end{array}$ \\
\hline \multirow[t]{16}{*}{ Solanaceae } & $\begin{array}{l}\text { Datura stramonium } \mathrm{L} . \\
\text { Hyoscyamus niger } \mathrm{L} \text {. } \\
\text { Lycopersicon esculentum Mill. } \\
\text { 'Kondine Red' }\end{array}$ & $\begin{array}{l}+ \\
+ \\
+\end{array}$ & $\begin{array}{l}+ \\
\dot{+}\end{array}$ & $\begin{array}{l}+ \\
\dot{+}\end{array}$ \\
\hline & $\begin{array}{l}\text { Nicotiana clevelandii Gray } \\
\text { N. debneyi Domin. }\end{array}$ & + & \pm & + \\
\hline & N. glutinosa $\mathrm{L}$. & + & + & - \\
\hline & N. rustica $\mathrm{L}$. & + & . & - \\
\hline & N. tabacum L. 'White Burley' & - & - & - \\
\hline & Petunia hybrida Villm. & + & - & - \\
\hline & Solanum chacoense Bitt. & + & - & $\cdot$ \\
\hline & $\begin{array}{l}\text { S. dulcamara } \mathrm{L} \text {. } \\
\text { S. nigrum } \mathrm{L} \text {. }\end{array}$ & $\begin{array}{l}+ \\
.\end{array}$ & $\begin{array}{l}+\mathbf{N} \\
+\end{array}$ & $\dot{\cdot}$ \\
\hline & S. stoloniferum Schlechdt. et Bché. & + & . & - \\
\hline & $\begin{array}{l}\text { S. tuberosum L. gp Andigena } \\
\text { S. tuberosum L. gp Chaucha }\end{array}$ & $\begin{array}{l}+\mathbf{N} \\
\mathbf{N}\end{array}$ & $\cdot$ & $\dot{.}$ \\
\hline & S. tuberosum L. gp Phureja & $\mathbf{N}$ & . & . \\
\hline & $\begin{array}{l}\text { S. tuberosum L. gp Tuberosum 'Arran } \\
\text { Victory' }\end{array}$ & $+\mathrm{G}$ & . & . \\
\hline & $\begin{array}{l}\text { S. tuberosum L. gp Tuberosum 'King } \\
\text { Edward' }\end{array}$ & $\mathbf{G}$ & · & - \\
\hline & S. tuberosum L. gp 'Tuberosum 'Majestic' & $+\mathbf{G}$ & $\mathrm{g}$ & . \\
\hline & $\begin{array}{l}\text { S. tuberosum L. gp Tuberosum 'Pentland } \\
\text { Beauty' }\end{array}$ & $\mathbf{G}$ & . & $\cdot$ \\
\hline & S. verrucosum Schlechdt. & + & . & - \\
\hline Umbelliferae & $\begin{array}{l}\text { Daucus carota L. 'Sutton Intermediate' } \\
\text { Pastinaca sativa } \mathbf{L} \text {. 'The Student' }\end{array}$ & - & - & - \\
\hline
\end{tabular}


inoculation with DMV. In several experiments during the summer a total of about two hundred $S$. dulcamara plants grown from one batch of seed were inoculated but none was infected. When, in the autumn, a few plants were grown from the same batch of seed and inoculated all were infected as were several hundred seedlings from three other batches of seed.

Ononis yellow mosaic virus. In cool weather the inoculated and tip leaves of Pisum sativum L. Onward developed a severe yellowing and necrosis and the plants died. In warm weather there was less necrosis, the plants recovered, and leaves produced later showed a brilliant yellow mosaic (Pl. 1, fig. 5). A few isolates from Devon gave milder symptoms even in cool weather. OYMV caused a more or less brilliant yellow mosaic in all its legume hosts. Of the three species of Solanaceae it infected, Nicotiana clevelandii showed a mild systemic mottling and necrotic flecking; only a few plants of the other two species became infected systemically and showed an indistinct chlorosis.

\section{Plant protection tests}

Tests were made to see whether plants systemically infected with one of the viruses resisted infection with one of the other two viruses using Nicotiana clevelandii for OYMV and either APLV or DMV, and Nicotiana glutinosa for APLV and DMV. About 3 weeks after plants were inoculated with one virus, leaves showing clear symptoms were inoculated with the second virus, and 2 weeks later sap from them was tested serologically for both viruses. None of the viruses protected plants against any other, and in each test the second virus infected already-infected plants as readily as comparable uninfected ones. The lack of protection was evident from symptoms, for the second virus produced more severe symptoms (usually necrotic lesions) on the already-infected plants than on the comparable uninfected ones.

\section{Properties of the viruses in sap}

Dilution end-point. The infectivity of sap from infected plants varied greatly. Usually the sap of inoculated leaves was most infective 2-4 weeks after the leaves had been inoculated, and was much more infective in winter than in summer. Sap of systemically infected leaves usually lost infectivity when diluted $10^{-3}$ to $10^{-5}$, though in one experiment sap of Nicotiana glutinosa infected with APLV was still infective when diluted $10^{-7}$.

Survival at different temperatures. Sap containing either DMV or OYMV retained some infectivity after $10 \mathrm{~min}$. at $65^{\circ}$, but not after $10 \mathrm{~min}$. at $70^{\circ}$ (Table 3). APLV withstood higher temperatures : although most infectivity was lost after $10 \mathrm{~min}$. at $75-80^{\circ}$, some remained after $10 \mathrm{~min}$. at $90^{\circ}$, but not at $100^{\circ}$. The plants infected with virus surviving at $85^{\circ}$ and $90^{\circ}$ showed the same symptoms as those inoculated with unheated sap; and virus preparations made from plants infected with these three types of inoculum were indistinguishable in serological tests and in the electron microscope. The same result was obtained in 3 experiments. Sap containing APLV or DMV usually remained infective at laboratory temperatures (about $20^{\circ}$ ) for only 2-7 days, whereas sap containing OYMV was still infective after 2 weeks. Similar saps stored at $+4^{\circ},-\mathbf{1 5}^{\circ}$, or dried while frozen were still infective after six months. 
Table 3. Survival at different temperatures

\begin{tabular}{|c|c|c|c|}
\hline \multirow{2}{*}{$\underset{\left({ }^{\circ}\right)^{*}}{\text { Temp. }}$} & \multicolumn{3}{|c|}{ Infectivity $\dagger$ of sap $\neq$} \\
\hline & APLV & DMV & OYMV \\
\hline Unheated & $100 \%(18 / 18)$ & $94 \%(17 / 18)$ & $93 \%(26 / 28)$ \\
\hline 60 & $100 \%(9 / 9)$ & $92 \%(11 / 12)$ & $81 \%(25 / 31)$ \\
\hline 65 & $100 \%(9 / 9)$ & $75 \%(9 / 12)$ & $40 \%(4 / 10)$ \\
\hline 70 & $72 \%(13 / 18)$ & $0 \quad(0 / 12)$ & $0 \quad(0 / 10)$ \\
\hline 75 & $100 \%(9 / 9)$ & $(0 / 12)$ & $(0 / 28)$ \\
\hline 80 & $22 \%(4 / 18)$ & $(0 / 6)$ & 一 \\
\hline 85 & $11 \%(1 / 9)$ & - & - \\
\hline 90 & $11 \%(1 / 9)$ & $(0 / 6)$ & $(0 / 4)$ \\
\hline 100 & $0 \quad(0 / 9)$ & - & - \\
\hline
\end{tabular}

* Sap heated at indicated temperature for 10 minutes.

+ Infectivity: percentage of plants infected; in parentheses, numerator is the number of plants infected, denominator is the total number of plants inoculated. Total of three experiments with each virus.

† Sap containing APLV and DMV from Nicotiana glutinosa, tested on the same species, sap containing OYMV from pea tested on either pea or Trifolium incarnatum.

\section{Properties of purified preparations}

Electron microscopy. Extracts of plants of Nicotiana glutinosa infected with APLV, of Solanum dulcamara and N. glutinosa infected with DMV, and of Ononis repens and Pisum sativum infected with OYMV all contained many approximately spherical particles, not found in comparable preparations from healthy plants. In the best electron micrographs the particles of all three viruses were indistinguishable in size and morphology from those of turnip yellow mosaic virus (Huxley \& Zubay, 1960; Nixon \& Gibbs, 1960) and cocoa yellow mosaic virus (Brunt et al. 1965). Some of the particles in negatively stained preparations were penetrated by the stain and were visible only as outlines, and the intact particles not penetrated by the stain showed the same arrangement of morphological subunits as turnip yellow mosaic virus (Pl. 1, fig. 6).

Centrifugation. In the analytical centrifuge purified preparations of the three viruses produced two boundaries, with sedimentation coefficients $\left(S_{20}, w\right)$ for APLV of $52 \mathrm{~S}$ and $112 \mathrm{~S}$, for DMV of $55 \mathrm{~S}$ and $121 \mathrm{~S}$, and for OYMV of $56 \mathrm{~S}$ and $114 \mathrm{~S}$ (the standard errors of these estimates were from $\pm 1 \cdot 1$ to $\pm 0 \cdot 03$ ). The sedimentation rate was only slightly dependent on the concentration of the virus present, and increased by about $2-4 \mathrm{~S}$ when the viruses were diluted from 5 to $0.25 \mathrm{mg}$. $/ \mathrm{ml}$. These two components, similar to the two in preparations of turnip yellow mosaic virus (Markham \& Smith, 1949), consisted of faster-sedimenting intact nucleoprotein particles and slower-sedimenting protein particles with the same external morphology as the intact particles. Some preparations of both DMV and OYMV also contained a third component with a sedimentation coefficient of about $95 \mathrm{~S}$. Such preparations were made from normal stock cultures of the viruses and had received the same treatment as the preparations which contained only two components.

Reichmann (1965) showed that, if various assumptions are made, the nucleic acid content of the nucleoprotein particles of a virus can be calculated, if preparations of the virus also contain 'empty' protein particles from the formula

$$
P=\left(S_{F} / S_{E}-1\right) /\left(S_{F} / S_{E}+1\right)
$$


where $\boldsymbol{P}$ is the percentage of nucleic acid in the 'full' nucleoprotein particles and $S_{F}$ and $S_{E}$ the sedimentation coefficients of the 'full' and 'empty' particles respectively. This formula applied to these three viruses gives a nucleic acid content of the nucleoprotein particles for APLV of $36.6 \%$, for DMV of $37.5 \%$, and for OYMV of $34 \cdot 1 \%$.

When centrifuged in sucrose density gradients the preparations of the viruses separated into two light-scattering layers. Some experiments comparing the properties of these layers were done using DMV, as this produces countable local lesions on Nicotiana glutinosa leaves. In one, samples were taken from both lightscattering layers, and from above them, between them and below them. The samples were dialysed against $0.03 \mathrm{M}$ phosphate buffer $\mathrm{pH} 7.0$ and then examined in the electron microscope. The top light-scattering layer contained mostly particles penetrated by the phosphotungstate, whereas the bottom one contained mostly intact particles. The five samples were each rubbed on to 10-16 leaves of $N$. glutinosa and, starting with the uppermost sample, produced 0, 0.4 (top layer), 16, 94 (bottom layer), and $\mathbf{3 \cdot 2}$ lesions per leaf. Thus the bottom layer sample was the most infective, contained most intact particles $\left(2.5 \times 10^{13}\right.$ particles $/ \mathrm{ml} ., 65 \%$ apparently intact, $\mathbf{3 5} \%$ empty, partly empty or damaged), and had the ultraviolet absorption spectrum of a nucleoprotein with a peak of absorption at $263-265 \mathrm{~m} \mu$ wavelength. The other less infective samples contained fewer intact particles; for example, the sample of the top light-scattering layer, which gave $\mathbf{0 . 4}$ lesion/leaf, contained $1.7 \times 10^{13}$ particles $/ \mathrm{ml}$, only $13 \%$ of which seemed to be intact, and had the ultraviolet absorption spectrum of a protein-nucleoprotein mixture with a broad peak of absorption at about $270 \mathrm{~m} \mu$ wavelength. In gel diffusion serological tests, only samples from the light scattering layers and from between them gave lines of precipitate. Each sample gave only one line of precipitate and, in a suitably designed test, the lines from different samples were confluent.

Effect of base analogues on virus components. Francki \& Matthews (1962) found that spraying plants infected with TYMV with 2-thiouracil solutions decreased the number of 'full' particles and greatly increased the proportion of non-infective 'empty' particles they contained. We sprayed Nicotiana glutinosa infected with either APLV or DMV with aqueous solutions (100 mgm./l.) of the five base analogues, 2-thiouracil, 6-azauracil, thioadenine, thiocytosine, and thioguanine and found that the first two, but not the last three, affected the amount of 'full' and 'empty' particles, which were extracted from the plants (Table 4). Spraying with thiouracil solution halved the total amount of virus produced, whereas azauracil increased it. Both analogues decreased the number of 'full' particles, and increased the relative proportion of 'empty' particles by about four times.

Nucleic acid analysis. The analyses (Table 5) show that the nucleic acids of the three viruses have similar base compositions. The large amount of cytidylic acid and small amount of guanylic acid accounts for the peak in the ultraviolet absorption spectrum being at 263-265 $\mathrm{m} \mu$ rather than a shorter wavelength.

Serology. The three viruses are serologically different but are related to each other. Antigenically APLV and DMV have more in common with each other than with OYMV, and most of the tests using absorbed sera confirmed this conclusion (Table 6). However, the results of the tests with OYMV antiserum were anomolous, for absorbing OYMV antiserum with excess of either APLV or DMV decreased its 
titre with OYMV from $1 / 512$ to $1 / 128$, whereas unabsorbed OYMV antiserum had a titre of only $1 / 16$ when titrated against these two viruses.

Many of the tests showed that the antibodies common to OYMV and APLV antisera differed from those common to OYMV and DMV antisera. For example,

Table 4. The effect of base analogues on APLV in Nicotiana glutinosa

\begin{tabular}{lcccc}
\multicolumn{1}{c}{ Spray* } & \multicolumn{3}{c}{ Relative particle content of sap $\dagger$} \\
\cline { 2 - 5 } & Total & 'Fulls' & 'Empties' & 'E'/'F' \\
Water & 100 & 77 & 23 & $0 \cdot 3$ \\
2-thiouracil (100 mg./l.) & 57 & 27 & 30 & $1 \cdot 1$ \\
6-azauracil (50 mg./1.) & 135 & 60 & 75 & $1 \cdot 25$
\end{tabular}

* Plants sprayed five times, starting 8 days after inoculation and then on alternate days. Plants harvested 3 weeks after inoculation.

$\dagger$ Virus purified by centrifugation, as described in text, and suspended in neutral $0 \cdot 1 \mathrm{M}-\mathrm{KCl}$. Relative amount of 'full' and 'empty' particles in the preparation estimated in the analytical centrifuge; all calculated relative to the total area of the two major peaks in the schlieren diagram produced by the virus preparation from water sprayed plants.

Table 5. Molar base composition of the viruses

\begin{tabular}{|c|c|c|c|c|}
\hline Virus & Guanine & Adenine & Cytosine & Uracil \\
\hline APLV & $15 \cdot 2 \pm 0 \cdot 5$ & $21 \cdot 6 \pm 0 \cdot 3$ & $34 \cdot 0 \pm 0 \cdot 3$ & $29 \cdot 2 \pm 0 \cdot 2$ \\
\hline DMV & $16 \cdot 7 \pm 0 \cdot 3$ & $22.6 \pm 0.4$ & $32 \cdot 3 \pm 0 \cdot 3$ & $28.5 \pm 0.3$ \\
\hline OYMV & $15 \cdot 6 \pm 0 \cdot 3$ & $21 \cdot 0 \pm 0 \cdot 1$ & $34 \cdot 2 \pm 0 \cdot 1$ & $29 \cdot 4 \pm 0.3$ \\
\hline
\end{tabular}

Table 6. Serological tests

\begin{tabular}{|c|c|c|c|c|}
\hline \multirow[b]{2}{*}{ Antiserum } & \multirow[b]{2}{*}{ Absorbing antigen } & \multicolumn{3}{|c|}{ titres* } \\
\hline & & APLV & DMV & OYMV \\
\hline APLV & $\begin{array}{l}\text { APLV } \\
\text { DMV } \\
\text { OYMV } \\
\text { DMV, OYMV }\end{array}$ & $\begin{array}{c}1024 \\
0(4) \\
512 \\
1024 \\
256\end{array}$ & $\begin{array}{l}64 \\
0(2) \\
0(2) \\
64 \\
0(8)\end{array}$ & $\begin{array}{l}16 \\
0(2) \\
4 \\
0(2) \\
0(8)\end{array}$ \\
\hline DMV & $\begin{array}{l}\text { APLV } \\
\text { DMV } \\
\text { OYMV } \\
\text { APLV, OYMV }\end{array}$ & $\begin{array}{l}64 \\
0(2) \\
0(2) \\
32 \\
0(8)\end{array}$ & $\begin{array}{l}512 \\
256 \\
\quad 0(2) \\
512 \\
256\end{array}$ & $\begin{array}{l}16 \\
8 \\
0(4) \\
0(2) \\
0(8)\end{array}$ \\
\hline OYMV & $\begin{array}{l}\text { APLV - } \\
\text { DMV } \\
\text { OYMV } \\
\text { APLV, DMV }\end{array}$ & $\begin{array}{l}16 \\
0(2) \\
8 \\
0(2) \\
0(8)\end{array}$ & $\begin{array}{l}16 \\
0(2) \\
0(2) \\
0(2) \\
0(8)\end{array}$ & $\begin{array}{c}512 \\
128 \\
128 \\
0(2) \\
128\end{array}$ \\
\hline $\begin{array}{l}\text { TYMV (1024 }) \\
\text { WCMV (1024) } \\
\text { CYMV (512) } \\
\text { RCMV (1024) } \\
\text { SMV (1024) }\end{array}$ & $\begin{array}{c}- \\
- \\
-\end{array}$ & $\begin{array}{l}0(2) \\
0(8) \\
0(2) \\
0(1) \\
0(1)\end{array}$ & $\begin{array}{l}0(2) \\
0(8) \\
0(2) \\
0(1) \\
0(1)\end{array}$ & $\begin{array}{l}0(2) \\
0(8) \\
0(2) \\
0(1) \\
0(1)\end{array}$ \\
\hline
\end{tabular}

* Reciprocal of dilution end-point after $4 \mathrm{hr}$ incubation at $37^{\circ}$. When no reaction least dilution tested given in parentheses.

$\dagger$ Homologous antiserum titre. 
DMV antiserum absorbed with excess APLV had the same homologous titre as that absorbed with excess of both APLV and OYMV, whereas APLV antiserum absorbed with an excess of both DMV and OYMV had half the homologous titre of the same serum absorbed with DMV alone. Similarly, OYMV antiserum absorbed with DMV still reacted with APLV, whereas when absorbed with APLV it did not react with either DMV or APLV. Tests using sera absorbed with excess of both the other two viruses showed that about a quarter to a half of the antibodies in each serum were specific for the homologous virus.

The precipitation end-points of the sera were the same when titrated against different isolates of the homologous virus. Four isolates of APLV from potato clones were tested: C.P.C. Nos. 2828, 2942, 3190 and 3195 (Table 1), one OYMV isolate from Wales and another from Dawlish (Devon), and two isolates of DMV.

APLV, DMV and OYMV did not precipitate with antisera prepared against turnip yellow mosaic (TYMV), wild cucumber mosaic (WCMV), cocoa yellow mosaic (CYMV), red clover mottle (RCMV), and squash mosaic viruses (SMV) (Table 6).

\section{DISCUSSION}

These three viruses, which we will call the Andean potato latent group, seem not to have been described before. They are particularly interesting as a group in that though they are readily distinguished in serological tests and by their host ranges, they have particles with indistinguishable morphology, size, sedimentation behaviour and base composition. They also share many of their properties with some previously known viruses, especially those transmitted by beetles (Fig. 4). They most closely resemble the viruses of the turnip yellow mosaic group (turnip yellow mosaic, wild cucumber mosaic, and cocoa yellow mosaic viruses): the particles are of the same morphology, size, and sedimentation behaviour, though they have a slightly different base composition, and are apparently serologically unrelated to them. However, these two groups share so many of their properties that it seems reasonable to consider the APL group to be a subgroup of the TYM group.

The APL group also share some properties, for example, particle size and sedimentation behaviour, with the cowpea mosaic group of viruses (cowpea mosaic (CMV), bean pod mottle(BPMV), red clover mottle, squash mosaic and radish mosaic (RMV) viruses); but viruses in this group have a very different base composition and morphology (in electron micrographs they do not show thirty-two morphological subunits and have an angular outline).

Other viruses that have been transmitted by beetles include southern bean mosaic (SBMV), turnip crinkle (TCV) and cocksfoot mottle (CFMV) viruses. These differ from viruses of the APL, TYM and CM groups in that purified preparations seem to consist only of 'full' particles, which sediment as one component and contain about $20 \%$ nucleic acid. Only viruses within each of the first three groups share common antigens.

Transmission of tobacco ringspot virus (TRSV) by flea beetles was reported by Schuster (1963). This is interesting as TRSV and other viruses of the ringspot group (e.g. grape vine fan leaf and yellow mosaic, arabis mosaic, tomato black ring, and raspberry ringspot viruses) have particles of the same size, morphology, and sedimentation behaviour as viruses of the cucumber mosaic (CM) group. TRSV also 
resembles viruses of the $\mathbf{C M}$ group in having uridylic acid as its most and cytidylic acid its least abundant nucleotide.

The beetle-transmitted viruses provide good examples of the characters that may be used either to group or separate viruses. Host-ranges and symptoms are usually not correlated with any specific features of the virus particles, or with their vectors, whereas various morphological and chemical features of the particles do seem to be correlated with one another and with the type of vector. These characters can provide the basis of a phenetic classification, which may be useful in the identification and prediction of properties of newly isolated viruses. With this objective we would distinguish the APL group by the following group of characters, which, though individually shared with various other groups of viruses, yet in combination seem to be unique.

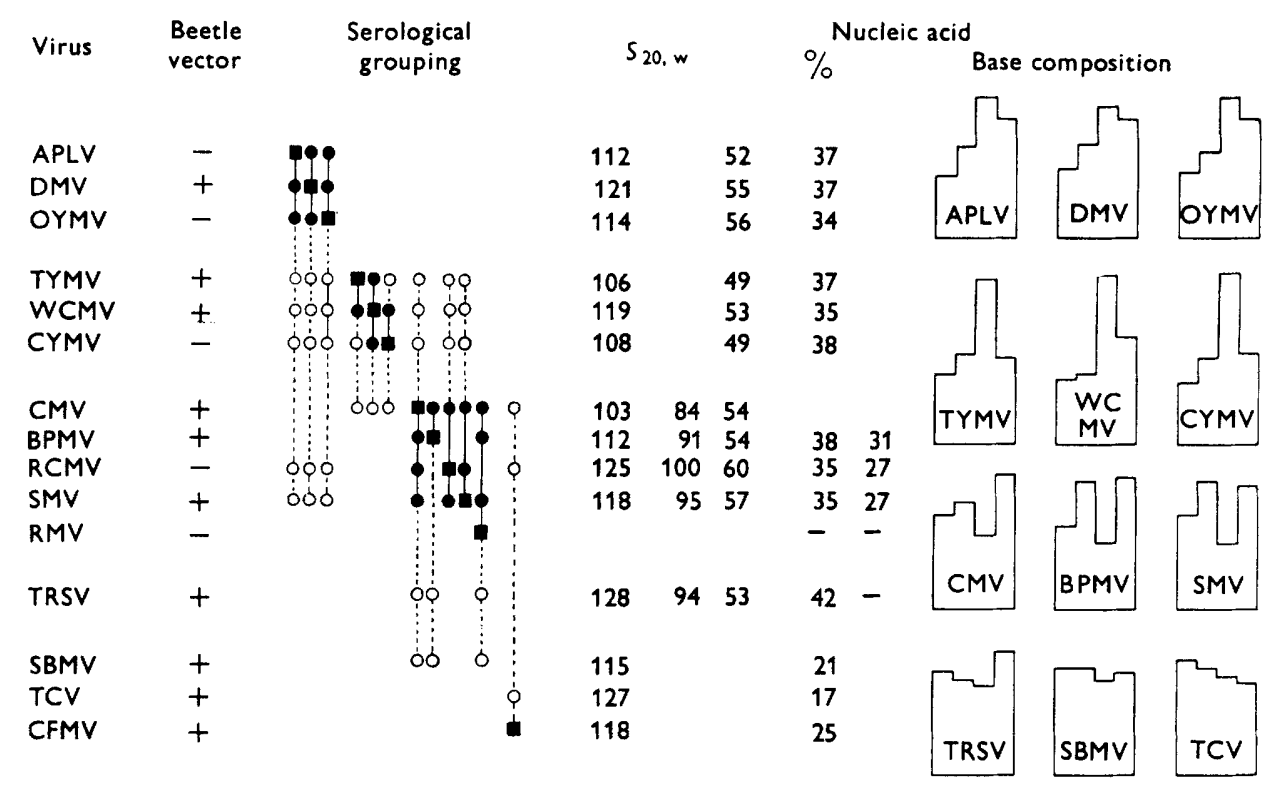

Fig. 4. Beetle-transmitted viruses. Virus name abbreviations in text. Serological relationships have been found between viruses joined by unbroken lines, but not between those joined with broken lines; antigen source marked with black square, antiserum circled. Nucleic acid molar base composition, left to right guanine, adenine, cytosine, uracil.

The data in Fig. 4 are from work in this paper and also Agrawal (1964), Bancroft (1962), Brunt, Kenten, Gibbs \& Nixon (1965), Campbell (1964), Dorner \& Knight (1953), Freitag (1952), Gibbs \& Guissani (unpublished results), Leberman (personal communication), MacLeod (personal communication), MacLeod \& Markham (1963), Markham (1959), Markham \& Smith, J. D. (1951), Markham \& Smith, K. M. (1949), Martini (1957), Mazzone, Incardona \& Kaesberg (1962), Miller \& Price (1946), Ross (1963), Shuster (1963), Semancik \& Bancroft (1964), E.P.Serjeant (to be published), Shepherd(1963), Stace-Smith, Reichmann \& Wright (1965), Symons, Rees, Short \& Markham (1963), van Velsen (persona] communication), Walters (1964a,b), Yamazaki \& Kaesberg (1961).

(1) Symptoms and host range. Limited host range, causing mosaic symptoms in most hosts, necrotic symptoms in very few. No 'recovery' from infection.

(2) Transmission. At least one of the group is beetle-transmitted, two are occasionally seed-transmitted, and all are readily sap transmitted. 
(3) Particles. Purified preparations of the virus contain two major components:

(a) Infective nucleoprotein particles, which are isometric, 25-30 $\mathrm{m} \mu$ in diameter, with 32 major morphological subunits when examined in neutral sodium phosphotungstate and which contain about $36 \%$ RNA with approximate base composition G $6 \%$ A $22 \%$ C $33 \%$ U $29 \%$.

(b) Non-infective protein particles of the same external morphology.

We are indebted to Dr R. Markham for advice on the nucleotide analyses, to Dr B. J. Selman, of the British Museum, who identified the insects, and to many other people who helped both technically and in the collection of samples.

\section{REFERENCES}

Agrawal, H. (1964). Identification of cowpea mosaic virus isolates. Meded. LandHogesch. Wageningen, p. 64.

Bancroft, J. B. (1962). Purification and properties of bean pod mottle virus and associated centrifugal and electrophoretic components. Virology, 16, 419.

Bawden, F. C. (1950). Plant Viruses and Virus Diseases, 3rd ed. Waltham, Mass., U.S.A.: Chronica Botanica.

Bos, L., Hagedorn, D. J. \& Quantz, L. (1960). Suggested procedures for international identification of legume viruses. Tijdschr. PlZiekt. 66, 328.

Brunt, A. A., Kenten, R. H., Gibbs, A. J. \& Nixon, H. L. (1965). Further studies on cocoa yellow mosaic virus. J. gen. Microbiol. 38, 81.

Campbeli, R. N. (1964). Radish mosaic virus, a crucifer virus serologically related to strains of bean pod mottle virus and to squash mosaic virus. Phytopathology, 54, 1418.

Dopds, K. S. (1962). Classification of cultivated potatoes. In The potato and its wild relatives. Ed. by D. S. Correll. Renner, Texas: Texas Research Foundation.

Dorner, R. W. \& KNight, C. A. (1953). The preparation and properties of some plant virus nucleic acids. J. biol. Chem. $205,959$.

Francki, R. I. B. \& Matthews, R. E. F. (1962). Some effects of 2-thiouracil on the multiplication of turnip yellow mosaic virus. Virology, 17, 367.

Freitag, J. H. (1952). Seven virus diseases of cucurbits in California. Phytopathology (abstr.), 42, 8.

Huxley, H. E. \& Zubay, G. (1960). The structure of the protein shell of turnip yellow mosaic virus. J. mol. Biol. 2, 180.

John Innes Institute (1960). Ann. Rep. Innes Inst. 51, 26.

John InNes Institute (1963). Ann. Rep. Innes Inst. 54, 37.

KATZ, S. (1962). Locating ultraviolet-absorbing substances on paper chromatographs. J. chem. Educ. 39, 34.

MacLeod, R. \& Markham, R. (1963). Experimental evidence of a relationship between turnip yellow mosaic virus and wild cucumber mosaic virus. Virology, 19, 190.

Mansi, W. (1958). Slide gel diffusion precipitin test. Nature, Lond. 181, 1289.

Markham, R. (1955). Modern Methods of Plant Analysis. Ed. by K. Paech \& M. V. Tracey, vol. 4, p. 246.

MarkmaM, R. (1959). In The Viruses. Ed. by F. M. Burnet \& W. M. Stanley, vol. 2. chap. 2. New York and London: Academic Press.

MaRKhaM, R. (1960). A graphical method for the rapid determination of sedimentation coefficients. Biochem. J. 77, 516.

Markham, R. \& Sмrth, J. D. (1951). Chromatographic studies of nucleic acids. Biochem. J. 49, 401.

MarkhaM, R. \& Smith, K. M. (1949). Studies on the virus of turnip yellow mosaic. Parasitology, 39, 330. 


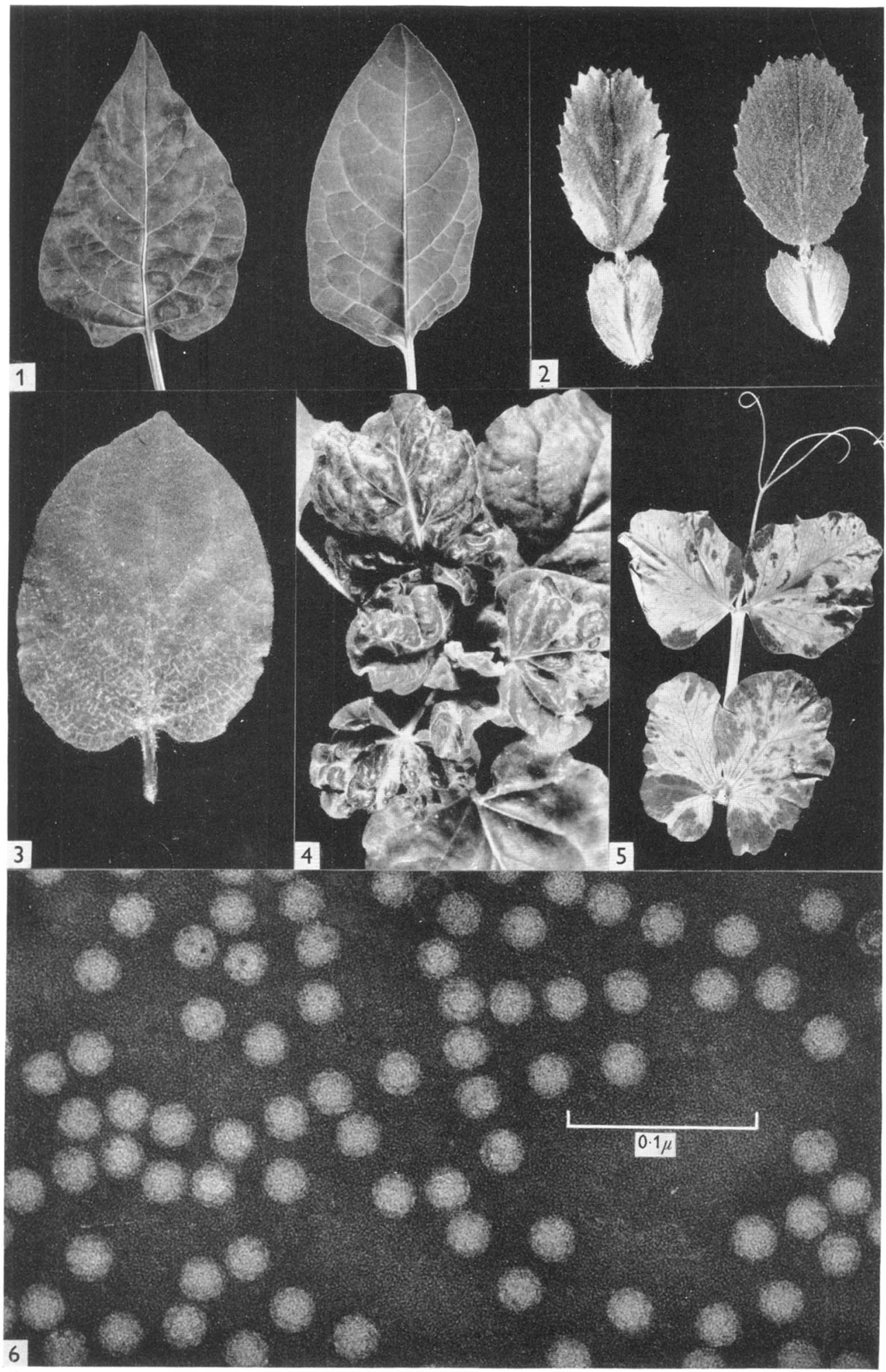


Martini, C. (1957). The transmission of turnip viruses by biting insects and aphids. Proc. 3rd Conf. Potato Virus Diseases, p. 106.

Mazzone, H. M., Incardona, N. L. \& Kaesbeng, P. (1962). Biochemical and biophysical properties of squash mosaic virus and related macromolecules. Biochim. biophys. Acta, 55,164 .

MCKEe, R. K. (1964). Virus infection in South American potatoes. Eur. Potato J. 7, 145.

Miller, G. L. \& Price, W. C. (1946). Physical and chemical studies on southern bean mosaic virus. Archiv. Biochem. 10, 467.

Nixon, H. L. \& GibBs, A. J. (1960). Electron microscope observations on the structure of turnip yellow mosaic virus. J. mol. Biol. 2, 197.

Nixon, H. L. \& Harrison, B. D. (1959). Electron microscopic evidence on the structure of tobacco rattle virus. J. gen. Microbiol. 21,582 .

Perring, F. H. \& Walters, S. M. (1962). Atlas of the British Flora. London: Thomas Nelson.

Reichmann, M. E. (1965). Determination of ribonucleic acid content of spherical viruses from sedimentation coefficients of full and empty particles. Virology, 25, 166.

Ross, J. P. (1963). Transmission of bean pod mottle virus in soybeans by beetles. Pl. $\mathrm{Dis}$. Reptr, 47, 1049.

Schuster, M. F. (1963). Flea beetle transmission of tobacco ringspot virus in the lower Rio Grande Valley. Pl. Dis. Reptr, 47, 510.

Semancik, J. S. \& Bancroft, J. B. (1964). Further characterization of the nucleoprotein components of bean pod mottle virus. Virology, 22, 33.

Shepherd, R. J. (1963). Serological relationship between bean pod mottle virus and cowpea mosaic virus from Arkansas and Trinidad. Phytopathology, 53, 865.

Sinha, R. C. (1960). Red clover mottle virus. Ann. appl. Biol. 48, 742.

Stace-Smith, R., Reichmann, M. E. \& Wright, N. S. (1965). Purification and properties of tobacco ringspot virus and two RNA-deficient components. Virology, 25, 487.

Steere, R. L. (1956). Purification and properties of tobacco ringspot virus. Phytopathology, 46, 60 .

Symons, R. H., Rees, M. W., Short, M. N. \& Markmam, R. (1963). Relationships between the ribonucleic acid and protein of some plant viruses. J. mol. Biol. 6, 1.

Walters, H. J. $(1964 a)$. Transmission of bean pod mottle virus by bean leaf beetles. Phytopathology, 54, 240.

Walters, H. J. $(1964 b)$. Transmission of southern bean mosaic virus by the bean leaf beetle. Pl. Dis. Reptr 48, 935 .

Yamazaki, H. \& Kaesberg, P. (1961). Biophysical and biochemical properties of wild cucumber mosaic virus and two related virus-like particles. Biochim. biophys. Acta, 51,9 .

\section{EXPLANATION OF PLATE}

Fig. 1. Solanum dulcamara leaves; left infected with DMV, right healthy.

Fig. 2. Ononis repens leaves; left infected with OYMV, right healthy.

Fig. 3. Nicotiana glutinosa leaf systemically infected with APLV.

Fig. 4. Nicotiana glutinosa plant systemically infected with DMV.

Fig. 5. Pisum sativum leaf systemically infected with OYMV.

Fig. 6. Electron micrograph of purified APLV bottom component mounted in neutral sodium phosphotungstate. 